\title{
BENCHMARKING ENERGY EFFICIENCY OF SCHOOL BUILDINGS
}

\author{
Džana Kadrić, Nijaz Delalić, Berina Delalić, Edin Kadrić, Hadis Bajrić
}
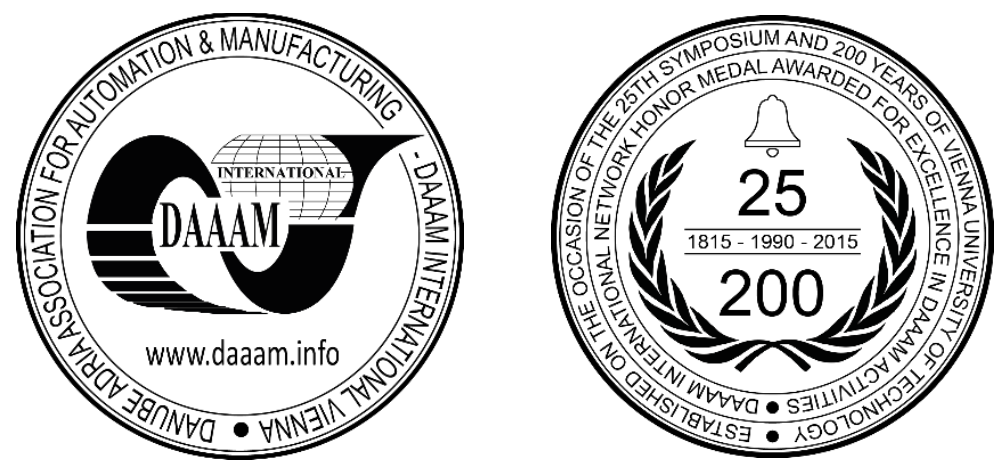

This Publication has to be referred as: Kadric, D[zana]; Delalic, N[ijaz]; Delalic, B[erina]; Kadric, E[din] \& Bajric, H[adis] (2018). Benchmarking Energy Efficiency of School Buildings, Proceedings of the 29th DAAAM International Symposium, pp.0299-0305, B. Katalinic (Ed.), Published by DAAAM International, ISBN 978-3-902734-20-4, ISSN 1726-9679, Vienna, Austria

DOI: $10.2507 / 29$ th.daaam.proceedings.043

\begin{abstract}
Energy efficiency of primary and secondary schools in city of Sarajevo is analysed and assessed. Building stock is represented using the building matrix with typical building and typical heating system for characteristic construction periods. Buildings from construction period with highest portion of buildings and energy need for heating are chosen for detailed analysis. Annual energy need for heating for each building is calculated in line with BAS EN ISO 13790 and compared with limiting values of specific, annual energy need for heating for new buildings. Results have shown that analysed category has energy saving potential higher than $77 \%$. Energy efficiency improvement strategy included implementation of three standard architectural and construction refurbishment measures on buildings envelope. Corresponding energy and energy cost savings are calculated. Linear combination method is used to define a model which could be used for prediction of total investment benefit (total energy/energy cost savings per investment) for analysed category. Analysis is performed to target buildings for which refurbishment measures provide best combination of energy and/or energy cost savings. Results of buildings ranking, in analysed category, is shown. This information is of crucial importance for making the refurbishment strategy for targeted building stock.
\end{abstract}

Keywords: energy efficiency benchmarking; refurbishment strategy; school buildings; linear combination model; ranking

\section{Introduction}

Energy use in public sector in Bosnia and Herzegovina contributes significantly to a total energy consumption. National Energy Efficiency Action Plan (NEEAP) sets the national indicative target for energy reduction in residential and public building sectors, industry and other sectors for 2018 [1]. Baseline for final energy consumption indicator for the commercial sector and services was set to Final Energy Consumption (FEC) of 2.780,6 GWh for 2018. It is expected that total energy savings owed to energy-efficient renovation of existing and sustainable construction of new buildings will reach 180.55 GWh. Using the Monitoring Verification Platform (MVP) developed for energy savings reporting [2], total of 23,6 GWh of final energy savings is reported as a result of various refurbishment measures implemented in the previous period in all sectors. Taking into account that not all the refurbishment measures are inserted in MVP, it is still clear that there is a large potential for energy savings in residential and public building sectors in Bosnia and Hercegovina. 
In the previous period, building typologies for residential and public building sectors in Bosnia and Hercegovina are completed and published [3] [4]. They provide valuable information about the building stock of both sectors regarding the architectural characteristic of buildings through the chosen building periods. For each time period several representative buildings are presented together with an overview of the most important energy characteristics (energy need for heating, delivered energy, $\mathrm{CO}_{2}$ emission and other). Building typologies are based on wide-ranged statistical investigation which had focus on architectural characteristics of residential and public building sectors. By introducing some modifications of typology results, building typology for residential sector could be a very useful tool for estimation of total energy use for heating and its structure for a complete residential building sector in Bosnia and Hercegovina [5]. In the previous period, several regions and cities adopted their energy efficiency improvement action plans and therefore the implementation of energy efficiency projects will experience significant increase in the following years. Accordingly, it is of great use to approach this process in a manner that will provide the most efficient refurbishment and generate highest energy and energy cost savings.

Various statistical analysis models for energy benchmarking and refurbishment strategies have proven to be a powerful tool which could be useful for decision making process for authorities. Very useful literature is a review article which presents summary of different models of data envelopment analysis (DEA) that have been applied around the world to address energy efficiency problems. It presents a review of 144 papers published between years 2006. and 2015. and shows that DEA promises to be a good evaluative tool for future analysis on energy efficiency issues. [6].

There is very limited number of published results that offer a statistically based refurbishment analysis in Bosnia and Herzegovina, so this paper is focused on findings in the area of energy benchmarking with the aim to provide support in decision making process for designing the cost optimal and energy effective refurbishment strategy. In this area, quality assurance of input data is of crucial importance. Therefore, in this analysis, attention is focused on one category of energy consumer: primary and secondary schools in Sarajevo. Based on the findings from several detail energy audits, it has been determined that energy need for heating is dominant in the distribution of energy consumption and energy costs. Also, energy savings potential is significant in this area [7], so attention is focused on energy need for heating and architectural and construction refurbishment measures which will provide energy savings.

\section{Energy efficiency benchmarking}

For defining energy efficiency benchmark and saving potentials in targeted category, findings from Energy efficiency study performed for Canton Sarajevo [8] as well as preliminary and detail energy audits performed on schools in Sarajevo are considered. Analysis have taken into account 115 schools, which represent share of more than $90 \%$ of total number of schools. Collected data were from year 2016 [8] and period from 2013 - 2017 (Preliminary and detail energy audits). Total useful, heated area of analysed building stock is $313.900,00 \mathrm{~m}^{2}$.

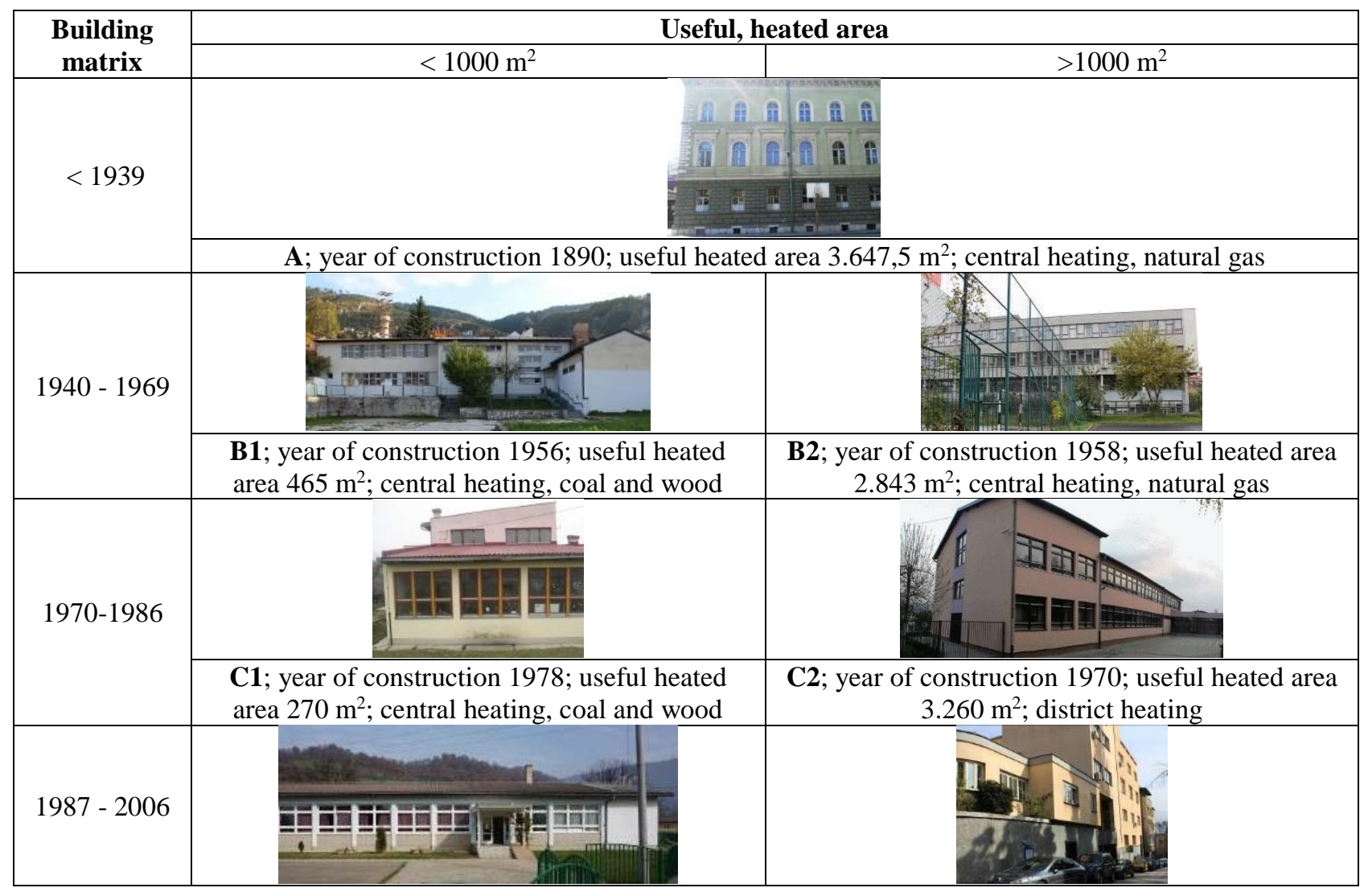




\begin{tabular}{|c|c|c|}
\hline \multirow{3}{*}{$\begin{array}{l}\text { Building } \\
\text { matrix }\end{array}$} & \multicolumn{2}{|c|}{ Useful, heated area } \\
\hline & $<1000 \mathrm{~m}^{2}$ & $>1000 \mathrm{~m}^{2}$ \\
\hline & $\begin{array}{l}\text { D1; year of construction 2001; useful heated } \\
\text { area } 300 \mathrm{~m}^{2} \text {; central heating, various }\end{array}$ & $\begin{array}{c}\text { D2; year of construction 1995; useful heated area } \\
3.028 \mathrm{~m}^{2} \text {; central heating, natural gas }\end{array}$ \\
\hline \multirow[t]{2}{*}{$>2007$} & III & $\begin{array}{l}\text { i } \\
\text { it }\end{array}$ \\
\hline & $\begin{array}{l}\text { E1; year of construction 2015; useful heated } \\
\text { area } 250 \mathrm{~m}^{2} \text {; central heating, natural gas }\end{array}$ & $\begin{array}{c}\text { E2; year of construction 2007; useful heated area } \\
3.626 \mathrm{~m}^{2} \text {; district heating }\end{array}$ \\
\hline
\end{tabular}

Table 1. Building matrix for primary and secondary schools in Sarajevo

It is useful to present the analysed building stock in a form of a building matrix. The building matrix gives a clear overview of typical objects that represent the individual building periods and the average values of category's useful area, as shown in Table 1. Periodization is influenced by application of regulation in the field of thermal protection of buildings while useful heated area is divided on two categories; buildings with heated area smaller than $1000 \mathrm{~m}^{2}$ and ones with the area higher than $1000 \mathrm{~m}^{2}$. Along with building matrix, most common heating system for every period is shown.

From the analysis which has taken into account more than 115 schools, it is shown that most dominant type of heating system is central heating with natural gas as a fuel. Following is district heating system with thermal substation, then central heating system with fuel oil as a fuel. Wood, coal and pellets are used in a small percentage of schools in Sarajevo.

In Fig. 1. an energy and water cost share for one school in Sarajevo is shown. This is a typical representation of actual energy costs share for school which uses natural gas as a fuel for heating system and electricity for lighting and various electrical devices. Actual costs are observed over a period of three years and averaged. It is visible that fuel costs have the highest share in total costs. This is a result of a high heat losses related to the poor thermal properties of building envelope and low efficiency of thermo-technical system (boiler, system of automatic control, distribution and emission), where a huge potential for energy savings lays in. Therefore, our attention was focused on energy need for heating.

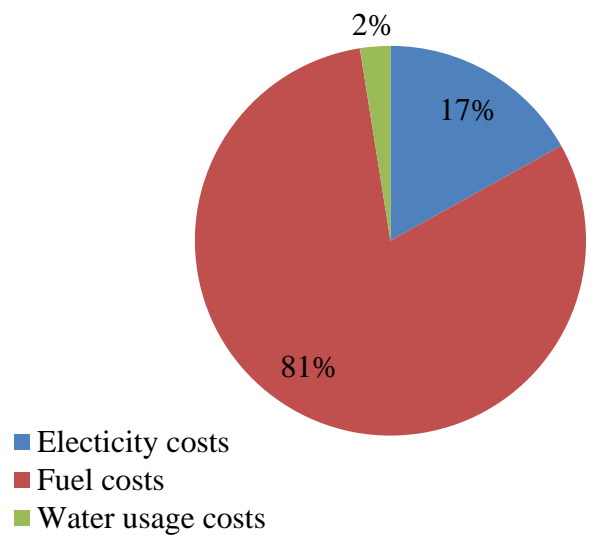

Fig. 1. Energy and water cost share in total costs

Based on the data from the energy efficiency study in Sarajevo, number of buildings and energy needs share in total energy consumption of the Sarajevo schools are calculated and presented in Table 2 by the characteristic construction periods. It is noticeable that category of buildings constructed in period from 1940 to 1969 have a highest share in total number of buildings and in energy use. Therefore, following detailed analysis is focused on this category.

\begin{tabular}{|c|c|c|}
\hline $\begin{array}{c}\text { Construction } \\
\text { period }\end{array}$ & $\begin{array}{c}\text { Category share } \\
\text { (number of buildings), \% }\end{array}$ & $\begin{array}{c}\text { Share of energy use for } \\
\text { heating, \% }\end{array}$ \\
\hline$<1939$ & 13,6 & 21,1 \\
\hline $1940-1969$ & 45,8 & 42,7 \\
\hline $1970-1986$ & 22,9 & 25,8 \\
\hline $1987-2006$ & 13,6 & 7,5 \\
\hline$>2007$ & 4,2 & 2,8 \\
\hline
\end{tabular}

Table 2. Number of buildings and energy use shares for different construction periods 
For every school from constructing period from 1940 - 1969, annual theoretical energy need for heating is calculated in line with BAS EN ISO 13790. Afterwards, annual energy need for heating is normalized with useful heated area of building resulting in specific annual energy need. For building energy certification purpose, some input parameters for calculation are standardized such as climatic data and building usage time prescribed for different building use. For the purpose of this analysis, climatic data for Sarajevo are used as an input data since theoretical energy use of building and saving potentials are to be determined. Also, actual usage time of building is taken into account. Calculated values of specific energy need for heating for different building shape factor are shown in Fig. 2.

For new buildings and buildings subjected to the major renovations, prescribed limiting values of specific, annual energy need for heating for different building usage and shape factor are defined in [9] and presented as a green line in Fig. 2. All values are given as a function of a building shape factor, which is a measure of the building's compactness and expresses the ratio between the building's thermal envelope area and its volume. It is proven that buildings with a smaller building shape factor have lower specific heat demand that buildings with the same thermal envelope properties and higher value of building shape factor [10].



Fig. 2. Values of specific energy need for heating for original state

From Fig. 2. it is visible that values of specific energy need for heating for every school are higher than values prescribed by the By-laws applicable to new buildings and buildings subjected to the major renovation. Therefore, buildings could be described as energy inefficient buildings. This is mainly a result of high ventilation and transmission losses related to the poor thermal envelope.

Analysing the values given in the Fig. 2. it is possible to determine the minimum energy saving potential as a difference between the actual value of the specific energy need of building and maximum allowed energy need (energy efficient building in Fig 1.). Minimum saving potential for the analysed building category is $77 \%$ of the calculated theoretical energy use for heating. Most common envelope refurbishment measures for buildings in B\&H includes measures that ensure envelope thermal characteristics better than the ones prescribed in By-law, so actual savings that could be accomplished are even higher.

\section{Energy efficiency improvement measures}

The experience gained from detail energy audits has shown that energy need for heating could be decreased by more than $50 \%$ by applying the thermal envelope improvements that are architectural and construction measures.

Standard improvement measures proposed for implementation in this study are defined in accordance with measures usually applied in the region and include:

- M1 - replacement of existing windows with new ones with $\mathrm{U}$ value ranging from 1,2 to $1,6 \mathrm{~W} / \mathrm{m}^{2} \mathrm{~K}$,

- M2 - adding a thermal insulation layer of $10 \mathrm{~cm}$ on external walls with resulting wall $\mathrm{U}$ values smaller than 0,40 $\mathrm{W} / \mathrm{m}^{2} \mathrm{~K}$

- M3 - adding a thermal insulation layer of 10 to $15 \mathrm{~cm}$ between upper floor and unheated attic (on the upper side) or on the flat roof (along with humidity protection layers). Resulting $U$ values of attic or roof are smaller than 0,35 $\mathrm{W} / \mathrm{m}^{2} \mathrm{~K}$.

Energy savings are result of significant reduction of ventilation losses when applying measure M1 or reduction of transmission losses when applying measures M2 or M3. For all proposed measures, energy savings and investment cost are calculated for every building from the chosen building category (construction period 1940 - 1969). 
Resulting specific energy need for heating when applying improvement measures is shown in Fig. 3. It is noticeable that, application of each measure separately will decrease the specific energy need for heating, but buildings will still be rated as an energy in-efficient. Therefore, it is useful to explore the implementation of several measures on one object but in the manner that will ensure maximum energy and cost savings. Using linear combination method, the relations which describe energy savings/energy cost savings as a function of investment cost for three energy efficient improvement measures are developed.

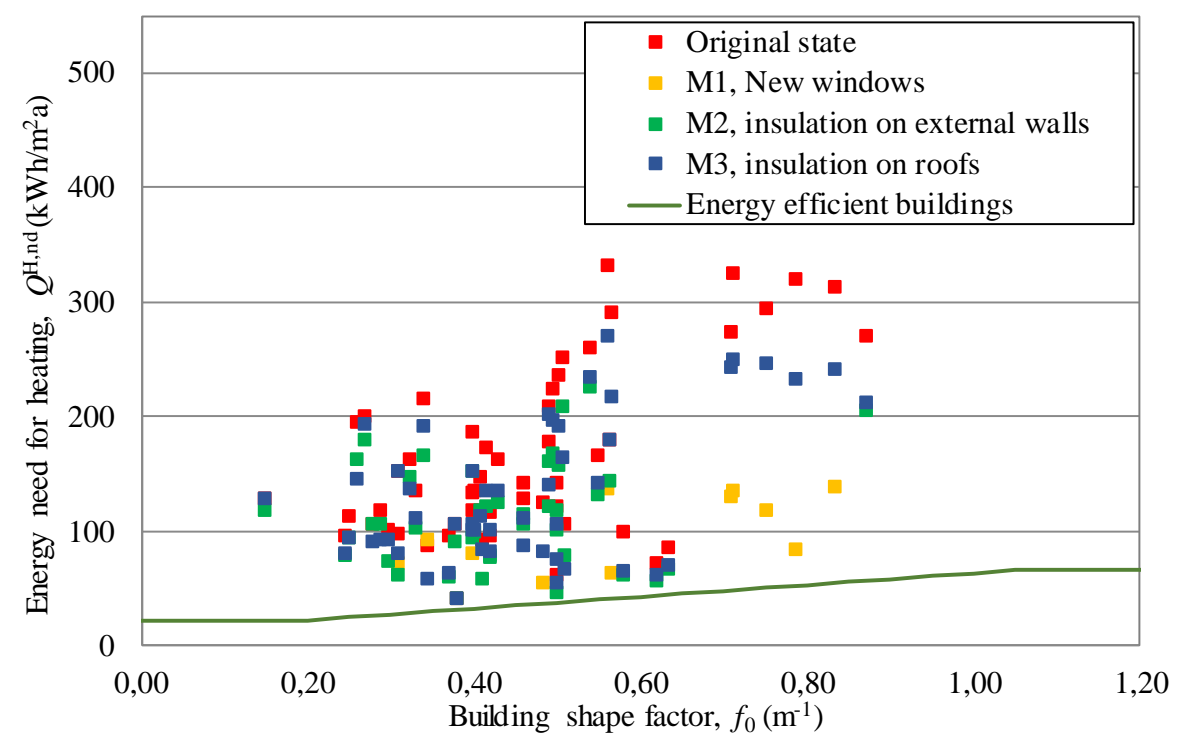

Fig. 3. Values of specific energy need for heating after refurbishment measures

Value of coefficient $\mathrm{K} 1$ which is a ratio of energy savings (kWh) and investment costs (BAM) is calculated for every building and every refurbishment measure. Following, coefficient K2, which represent a ratio of energy cost savings (BAM) and investment costs (BAM) is calculated for every building and implemented refurbishment measure. In calculation of energy cost savings, average efficiency of thermo-technical system in every building and typical cost for fuel in region is taken into account.

Average values of coefficients K1 and K2 for complete analysed category are given in Table 3 . These values serve as coefficients for linear combination model.

\begin{tabular}{|c|c|c|}
\hline Refurbishment measure & K1 (kWh/BAM) & K2 (BAM/BAM) \\
\hline M1 - Windows replacement & 0,726 & 0,096 \\
\hline M2 - Thermal insulation on external walls & 0,903 & 0,120 \\
\hline M3 - Thermal insulation on roofs & 0,881 & 0,121 \\
\hline
\end{tabular}

Table 3. Average values of K1 and K2 coefficient for selected building category (construction period 1940 - 1969)

From Table 3. it is noticeable that, when analysing the complete category, highest energy savings per investment could be achieved by applying the thermal insulation on external walls where there is also highest energy cost reduction. Following are investments in measure M3, then in measure M1.

Using the linear combination method, the following relations valid for the building category are derived:

- Energy savings, Esav:

$$
E \operatorname{sav}=0,726 * \text { Iwin }+0,903 * \text { Iwall }+0,881 * \text { Iroof }\left(\frac{\mathrm{kWh}}{\text { year }}\right),
$$

- $\quad$ Energy cost savings, ECsav:

$$
E C \operatorname{sav}=0,096 * I \text { win }+0,12 * I \text { wall }+0,121 * \text { Iroof }\left(\frac{\text { BAM }}{\text { year }}\right)
$$

where: Iwin, Iwall and Iroof are investment values for refurbishment measures M1, M2 and M3 in BAM. 
Using (2) it is possible to show that, for investment of 1,00 BAM (distribution 40\%, $30 \%, 30 \%$ for Iwin, Iwall and Iroof, respectively) energy savings are higher than $10 \%$ per year. Generally, this could indicate the investment return period of approximately 10 years for the analysed category.

Beside the presented relations, it is important to rank the buildings for which the $\mathrm{K} 1$ and $\mathrm{K} 2$ have highest values which means that their refurbishment provides best combination of energy and energy cost savings. This information is of crucial importance for making the refurbishment strategies for targeted building stock. Ranking was done by averaging their rank for the three measures using only K1 coefficient, since there is a strong correlation between K1 and K2 as seen in Table 3.. All objects are ranked from 1 to 53 while taking into account best combination of $\mathrm{K} 1$ for three refurbishment measures. In Table 4. results for ten best ranked object are shown with their actual specific energy need for heating.

\begin{tabular}{|c|c|c|}
\hline Building name & $\boldsymbol{Q}_{\mathbf{H}, \mathbf{n d}}\left(\mathbf{k W h} / \mathbf{m}^{\mathbf{2}} \mathbf{y e a r}\right)$ & Ranking \\
\hline Primary school "Hadžići - Binježevo" & 332 & 1 \\
\hline Primary school "Behaudin Selmanović" & 142 & 2 \\
\hline Secondary school "Treća gimnazija" & 116 & 3 \\
\hline Primary school "Edhem Mulabdić - Širokača" & 273 & 4 \\
\hline Primary school "Mirsad Prnjavorac" & 93 & 5 \\
\hline Primary school "Hilmi ef. Šarić - Korča" & 325 & 7 \\
\hline Secondary school "Druga gimnazija" & 216 & 8 \\
\hline Primary school "9. Maj - Lokve" & 290 & 9 \\
\hline Primary school "6. mart" & 186 & 10 \\
\hline Secondary school "Srednja škola za tekstil, kožu i dizajn" & 172 & 6 \\
\hline
\end{tabular}

Table 4. Results of schools ranking for highest energy savings by applying the refurbishment measures

\section{Conclusions}

Presented analysis has shown that there is a large potential for energy savings in primary and secondary schools in Sarajevo. With a presence of high heat transmission and ventilation losses related to the poor thermal properties of building envelope, this building stock is marked as suitable for implementation of refurbishment measures. It is of crucial importance to discover which buildings are priorities while designing the refurbishment strategies. This can be done by determining buildings for which refurbishment measures will result in highest energy savings and highest energy cost savings. In this work, it is presented how ratio of energy savings to investment could be used for decision making. Also, it is shown how to develop a relation between the energy savings and investment and between energy cost savings and investment for a whole building category.

Analysing values from Energy efficiency study in Canton Sarajevo [8] it is shown that category of school buildings constructed in period from 1940 to 1969 has a highest share in total number of school buildings and in energy use so detailed analysis is focused only on this category. Theoretical values of specific energy need for heating are calculated and compared with limiting values prescribed by the By-laws applicable to new buildings and buildings subjected to the major renovation. Analysis has shown that considered buildings could be described as energy inefficient. Minimum saving potential for the analysed building category is discovered to be $77 \%$ of the calculated theoretical energy use for heating. Standard improvement measures proposed in this paper include measures usually applied in the region: replacement of existing windows with new ones, adding a thermal insulation layer of $10 \mathrm{~cm}$ on external walls and adding a thermal insulation layer of 10 to $15 \mathrm{~cm}$ between upper floor and unheated attic (on the upper side) or on the flat roof (along with humidity protection layers). For all proposed measures, theoretical energy savings and investment cost are calculated for every building from considered category. The implementation of several measures on one object has been explored, but in the manner which will ensure maximum energy and energy cost savings.

Actual energy savings that could be accomplished are smaller than theoretical, since calculated theoretical energy need for heating takes into account internal temperature of $20^{\circ} \mathrm{C}$ for complete heating period and all heated area of object. This is however not fulfilled in some schools in region, so actual energy consumption for heating of object is most probably smaller than theoretical. Therefore, actual energy saving potential is smaller.

Linear combination method has been applied to define linear combination model which is then used to estimate and predict total investment benefit (total energy savings per investment). Coefficients of linear combination model are estimated as averages of expected energy savings when particular refurbishment has been applied. Collected data on energy savings per investment for particular refurbishment type (windows, thermal insulation of wall or roof) have been used to rank buildings. Final ranking of buildings is done by averaging their ranks per particular refurbishment type. This way buildings are ranked per total energy savings or investment benefit, which make particular building of high or low priority for refurbishment. Results for ten best ranked buildings are shown. 
These findings will provide very useful information regarding the energy saving potentials in primary and secondary schools in Sarajevo and can serve for decision making process for best refurbishment strategy for the analysed category.

In order to obtain objective criteria for stakeholder's selection of objects that require refurbishment, besides model presented in this paper, it is possible to use linear programming models. Linear programming models can be used for ranking objects that require refurbishment by numerus criteria, e.g. (1) maximum saving per unit investment, (2) maximum number of objects that can be refurbished with available budget, (3) selection of objects and types of refurbishment that will achieve maximum reduction of energy inefficiency with available budget, and (4) estimation of required (minimal) budget and selection of objects that require refurbishment in order to achieve targeted increase of energy efficiency of all objects.

Presented methodology for establishing the most efficient refurbishment strategy could be applied on every school category in Canton Sarajevo. This approach could also be applied on any other building category, for which data on investment and energy savings should be obtained. For particular category, new coefficient in linear combination model should be estimated. After careful planning of the energy efficiency improvements, special attention should be set towards the validation of energy and energy cost savings. Therefore, every refurbishment strategy should also include methodology which will enable validation of energy and energy cost savings.

\section{Acknowledgments}

This material is based upon work supported by the Ministry of Education, Science and Youth of Sarajevo Canton under Grant No. 11-05-14-21777/17.

\section{References}

[1] First National Energy Efficiency Action Plan 2010 - 2018 for Bosnia and Herzegovina, final draft (2011), Ministry of foreign affairs and economic relations of Bosnia and Herzegovina

[2] http://www.buildup.eu/en/practices/publications/monitoring-and-verification-platform-mvp-energy-efficiencyaction-plans, (2013). BUILD UP - The European Portal for Energy Efficiency in Buildings, Practices, Accessed on: $2018-02-23$

[3] Arnautović-Aksić D., Burazor M., Delalić N., Gajić d., Gvero P., Kadrić Dž., Kotur M., Salihović E., Todorović D. \& Zagora N. (2016), "Typology of residential buildings in Bosnia and Herzegovina, Faculty of Architecture, University of Sarajevo, ISBN 978-9958-691-51-5, Sarajevo

[4] Nišandžić M. et al. (2017), Typology of public buildings in Bosnia and Herzegovina, UNDP Bosnia and Herzegovina; original citation: Tipologija javnih zgrada u Bosni i Hercegovini

[5] Kadrić Dž., Živković B., Delalić N., Delalić B. \& Bešović I. (2018), The residential building national typology in the Republic of Serbia and in Bosnia and Herzegovina in the function of determination of needed and delivered energy for the residential sector, KGH - Klimatizacija, Grijanje, Hlađenje, God. 47, No. 1, 2018, pp. 67 - 78, ISSN 0350-1426

[6] Mardani, A., Kazimieras Zavadskas E., Streimikiene D., Jusoh A. \& Khoshnoudi M. (2017). A comprehensive review of data envelopment analysis (DEA) approach in energy efficiency, Renewable and Sustainable Energy Reviews, Vol. 70, pages 1298-1322, https://doi.org/10.1016/j.rser.2016.12.030

[7] Crnokić B., Lješić G., Stojkić Ž. \& Bandić-Glavaš M. (2017). Analysis of energy consumption in the building as the basis for development of the modular model predictive control system, Proceedings of the $28^{\text {th }}$ DAAAM International Symposium, 8-11 November 2017 Zadar, ISBN 978-3-902734-11-2, ISSN 1726-9679, B. Katalinic (Ed.), pp. $0299-0308$, Published by DAAAM International, Vienna, Austria, DOI: 10.2507/28th.daaam.proceedings.041

[8] Energy Efficiency Study for 300 Public Buildings in Sarajevo Canton (2016), ENOVA

[9] Rulebook on energy certification of objects (Draft version, 2018), Federal Ministry of Physical Planning, Federation of Bosnia and Herzegovina; original citation: Pravilnik o energetskom certificiranju objekata (Draft verzija), Federalno Ministartsvo prostornog uređenja, Federacija Bosne i Hercegovine

[10] Danielski I., Fröling M. \& Joelsson A. (2012). The impact of the shape factor on final energy demand in residential buildings in Nordic climates, Proceedings of World renewable energy forum (WREF), 13-17 May 2012 Denver, Colorado, ISBN: 978-1-938547-04-1, C. Fellows (Ed.), Published by American Solar Energy Society, Boulder, Colorado, USA 